\title{
Lemur Tyrosine Kinases and Prostate Cancer: A Literature Review
}

\author{
Elena Ferrari ${ }^{1, *,+}$, Valeria Naponelli ${ }^{1,2,3,+}$ (D) and Saverio Bettuzzi ${ }^{1,2,3}$ \\ 1 Department of Medicine and Surgery, University of Parma, Via Gramsci, 14, 43126 Parma, Italy; \\ valeria.naponelli@unipr.it (V.N.); saverio.bettuzzi@unipr.it (S.B.) \\ 2 National Institute of Biostructure and Biosystems (INBB), Viale Medaglie d'Oro 305, 00136 Rome, Italy \\ 3 Centre for Molecular and Translational Oncology (COMT), University of Parma, Parco Area delle \\ Scienze 11/a, 43124 Parma, Italy \\ * Correspondence: elena.ferrari@unipr.it; Tel.: +39-0521-033-822 \\ + These authors contributed equally to the work.
}

Citation: Ferrari, E.; Naponelli, V.; Bettuzzi, S. Lemur Tyrosine Kinases and Prostate Cancer: A Literature Review. Int. J. Mol. Sci. 2021, 22, 5453. https://doi.org/10.3390/

ijms22115453

Academic Editors:

Arkadiusz Orzechowski and Katarzyna Grzelkowska-Kowalczyk

Received: 30 March 2021

Accepted: 18 May 2021

Published: 21 May 2021

Publisher's Note: MDPI stays neutral with regard to jurisdictional claims in published maps and institutional affiliations.

Copyright: (C) 2021 by the authors Licensee MDPI, Basel, Switzerland. This article is an open access article distributed under the terms and conditions of the Creative Commons Attribution (CC BY) license (https:/ / creativecommons.org/licenses/by/ $4.0 /)$.

\begin{abstract}
The members of the Lemur Tyrosine Kinases (LMTK1-3) subfamily constitute a group of three membrane-anchored kinases. They are known to influence a wide variety of key cellular events, often affecting cell proliferation and apoptosis. They have been discovered to be involved in cancer, in that they impact various signalling pathways that influence cell proliferation, migration, and invasiveness. Notably, in the context of genome-wide association studies, one member of the LMTK family has been identified as a candidate gene which could contribute to the development of prostate cancer. In this review, of published literature, we present evidence on the role of LMTKs in human prostate cancer and model systems, focusing on the complex network of interacting partners involved in signalling cascades that are frequently activated in prostate cancer malignancy. We speculate that the modulators of LMTK enzyme expression and activity would be of high clinical relevance for the design of innovative prostate cancer treatment.
\end{abstract}

Keywords: prostate cancer; lemur tyrosine kinase; androgen receptor; Akt signalling; MAPK signalling

\section{Introduction}

Protein phosphorylation is one of the most common post-translational modifications. The dynamic process of phosphorylation is mediated by protein kinases, whose catalytic activity consists in the reversible phosphorylation of specific amino acid residues. This biochemical modification, where a phosphate group is donated by the high-energy ATP molecule, profoundly modifies the accepting protein substrate [1]. Such a modification introduces a charged, bulky, hydrophilic group (the phosphate) in the side chain of specific amino acids of the target protein, changing its conformation and interaction capability.

Together with the de-phosphorylation reactions, catalysed by specific phosphoprotein phosphatases, protein kinases contribute to many critical events in cell fate determination, cell cycle control, and signal transduction. Just as importantly, kinase deregulation is often associated with metabolic deregulation as well as several diseases. Therefore, over the last decades, protein kinases and phosphatases, both expressing a relevant regulatory potential in cell signalling, have become important targets for the pharmaceutical industry. Consistently, several kinase databases and resources provide up-to-date information on human kinome in physiological conditions and in association with diseases, as well as on the progress of kinome therapeutics [2].

Protein kinases have evolved to generate different kinase families, distinct in sequence, structure, and specificity [3,4]; the Tyrosine Kinase (TK) family stands out among them as a major research focus. In fact, members of the TK family, which exhibit a significant association with diseases, have been successfully targeted by chemical inhibitors. This is the case of Receptor Tyrosine Kinases (RTKs), regulatory signalling proteins governing cancer growth and metastasis. In physiological conditions, cell surface RTKs are 
activated when their extracellular domain is engaged with its ligand, typically a growth factor, thus inducing receptor dimerisation and tyrosine kinase activity [5-7]. RTKs autophosphorylate tyrosine residues in their cytosolic region, and engage many downstream signalling proteins, activating signal cascades that regulate cell replication, growth, differentiation, and survival [8]. Instead, in cancer cells, oncogenic alterations of RTKs (caused by mutations, genomic amplification, and chromosomal rearrangements) result in aberrant RTKs activation and downstream signal transduction, disrupting the balance between cell proliferation and cell death $[6,8]$. Since RTKs play crucial roles in cancer development, they represent molecular therapeutic targets for cancer treatment. In fact, many small molecule inhibitors have been developed for malignancies associated with mutated RTKs [7-10]. By targeting the ATP binding site (or an adjacent region), they specifically inhibit the tyrosine kinase function, prevent the phosphorylation of intracellular signal molecules, and block intracellular signal pathways that favour tumorigenesis. RTKs FDA-approved inhibitors, updated as of 18 August 2019, and their use in oncology has been accurately discussed by Pottier and co-workers [9]. Despite their success in cancer chemotherapeutics, acquisition of resistance to RTKs inhibitors inevitably develops. This is mainly attributed to RTK secondary mutations, which prevent the inhibitor from binding to the ATP pocket. To reduce drug resistance, recent approaches have been based on second- and third-generation RTKs inhibitors resistant to mutations, as well as on the combined use of synthetic with naturally derived RTKs inhibitors [7,11,12]. Another approach for targeting RTKs is based on monoclonal antibodies directed against the extracellular domains of the receptor, and aimed at interfering with RTK activation; their use has also been proposed in combination with tyrosine kinase inhibitors of the same RTK target [6,13].

Despite the importance of kinases in physiological conditions and their frequent mutation in disease, there is a substantial section of the human kinome that has remained little studied, up until now. This is what emerged from the NIH Illuminating the Druggable Genome (IDG) Program, aimed at identifying and providing information on proteins that are currently not properly studied within commonly drug-targeted protein families $[14,15]$.

The members of the Lemur Tyrosine Kinases (LMTKs) subfamily, located at a recent branch of kinase evolution, are on the list of the protein targets identified by the IDG Program for additional research (last updated on 11 June 2019). The published research studies on Lemur Tyrosine Kinases ( $n=53$ articles can be found in PubMed) of the last decade have mostly been dedicated to cancer and neurodegeneration investigations.

LMTKs comprise a novel group of three membrane-anchored kinases that, through a complex interactome network, regulates a wide variety of key cellular events, often impacting cell proliferation and apoptosis [16]. Current functional data support the hypothesis that LMTKs may regulate endosomal cargo recycling and move steroid receptors from the endocytic recycling compartment to the nucleus, where they can regulate the transcription of specific receptor-activated genes [16]. Although solid experimental evidence has substantiated various molecular functions of LMTKs, this protein kinase subfamily remains incompletely characterised.

Not unexpectedly, LMTKs have been discovered to be involved in cancer, as they affect various signalling pathways that severely influence cell behaviour, proliferation, migration, and invasiveness. Genome-wide association studies have identified seven loci of the human genome that are linked to prostate cancer (PCa) risk [17]. Indeed, one of these contains a LMTK gene. PCa is one of the most common cancers in Western countries. The major challenge that researchers face today is to identify PCa biomarkers which may help clinicians for an early diagnosis and a better treatment. Among the most promising PCa biomarkers is the evaluation of the expression levels of genes involved in the growth and survival of PCa cells and, in this regard, LMTK is a promising candidate gene [18]. 


\section{Prostate Cancer}

PCa represents the second most diagnosed cancer and the fifth most common cause of cancer death in men worldwide [19]. The incidence of PCa has grown significantly in the last decades due to increased diagnostic pressure and demographic ageing. The aetiology is complex, and the factors associated with PCa onset and progression are only partially determined. Many risk factors have been reported for this disease, including ethnicity, genetic predisposition, age, diet, family history, and lifestyle. The involvement of genetic factors is clearly shown by the higher incidence of PCa in men of African descent. They have the highest incidence and mortality rates, while Asian men have the lowest [20-23]. However, there are important differences in the specific mortality of individuals of the same ethnic group living in different countries and adopting different lifestyles; this shows that environmental factors play an important role in the onset of PCa [24].

PCa is a biologically heterogeneous disease $[25,26]$. It can develop into an aggressive form, which rapidly evolves to metastases, or remain in the body as an indolent form, which may remain undiagnosed for many years or even for the whole life of the patient. The most recommended treatment options are surgical removal of the gland, chemotherapy and/or radiotherapy. These therapeutic strategies are effective in the early phases of the pathology, before PCa becomes metastatic and turns into an aggressive and castrationresistant form (castration-resistant PCa, CRPC) [20]. In the latter case, cancer cells no longer respond to androgen deprivation therapy, a widely used therapy with the aim of slowing down the growth of PCa in its early phase of development [27]. Unfortunately, when PCa becomes aggressive or metastatic, this approach is ineffective and can be only envisaged as a palliative treatment.

Integrating molecular aspects of $\mathrm{PCa}$ into risk stratification remains a big challenge for clinical medicine. The ability to distinguish tumours with different clinical courses would both help to optimise the therapeutic strategy and allow for a reduction in overtreatment. Overtreatment is the unnecessary treatment of men with low-risk PCa that leads to a significant reduction in their quality of life because they do not need to be cured but could be treated with active surveillance. The identification of predictive genomic biomarkers is essential to achieving this objective. Recent research focuses on the clinical evaluation of genetic alterations associated with different outcomes of the disease [20,28-39]. To date, various chromosomal aberrations have been identified in PCa by novel approaches such as next generation sequencing [40-44]. Most patients present different profiles of alterations, involving more than 100 mutations in different genes, impacting PI3k/Akt/mTOR, MAPK and WNT signalling pathways, the cell cycle, and DNA repair [40].

Pursuing this line of research, here we present a narrative review of published literature on the role of LMTKs in PCa, with the aim of outlining the main research directions in this field of interest. Our analysis is complemented by an evaluation on the natural tyrosine kinase inhibitor Epigallocatechin-3-gallate and on the signalling pathways affected by this natural compound, with well-known anticancer and chemopreventive effects on prostate cancer cells.

\section{LMTK Proteins}

\subsection{LMTKs and Cancer}

The roles played by LMTKs in the cytosol and in the nuclear environment range from cell signalling and membrane trafficking to gene expression, explaining why their dysregulation can be associated with cancer $[16,45]$. A change in LMTK expression or protein level has been observed in different cancers, reflecting either positive or negative correlation dependent on cancer type. For example, LMTK2 protein level is high in colorectal and ovarian cancer, but is low in lymphoma, lung, testis, prostate, and renal cancer [45]. These findings suggest that LMTK level has the potential to be used as a diagnostic/prognostic biomarker. For instance, LMTK3 expression turned out to be a negative prognostic factor in patient with gastric cancer; its overexpression in bladder cancer was correlated with bladder cancer malignancy and predicted poor survival $[46,47]$. 
Many studies argue that LMTK proteins represent new potential targets for cancer therapy. Conti and co-workers showed that LMTK2 silencing sensitises immortalised epithelial and cancer cells to TNF-related apoptosis-inducing ligand (TRAIL) cytotoxicity, by regulating the levels of anti-apoptosis BCL2 family members [48]. Similarly, knockdown of LMTK2 inhibited the proliferation of colon cancer cells by inactivating nuclear factor- $\mathrm{kB}$ (NF-KB) [49], while LMTK2 silencing repressed the proliferation and invasion of hepatocellular carcinoma cells in vitro through the inhibition of Wnt/ $\beta$-catenin signalling [50]. All these findings suggest that LMTK2 inhibition might represent a valuable approach in the treatment of specific cancers.

The search for LMTK proteins inhibitors is ongoing. An ATP-competitive, LMTK3 small-molecule inhibitor has been identified by a high-throughput screening of a library of kinase inhibitor-biased compounds against the recombinant form of the catalytic domain of LMTK3. Biochemical, biophysical, and cellular assays contributed to the identification and characterisation of this inhibitor. Inhibition of LMTK3 decreased the proliferation of different human cancer cell lines, with a concurrent increase in apoptosis in breast cancer cell lines [51]. These findings pave the way for further development and optimisation of LMTK3 inhibitors.

\subsection{Catalytic Specificity of LMTKS}

The three structurally and evolutionary related Lemur Tyrosine Kinases, namely LMTK1, LMTK2, and LMTK3, constitute a family of regulated specific kinases that performs a diversified set of cellular functions, mainly involved in cell signalling and membrane trafficking [16]. Sequence homology with the kinase domain of Receptor Tyrosine Kinases (RTKs) suggested a tyrosine kinase catalytic activity for LMTK1 [52]. On the contrary, in vitro assays showed that LMTK2 exhibited only serine/threonine kinase activity in autophosphorylation reactions or with added substrates [53], disclosing the phospho-acceptor capability of this enzyme, as well. By analogy, LMTK1 and LMTK3 are to be regarded as serine/threonine kinases. Recent efforts to decipher LMTK3 consensus phosphorylation motif by using a positional scanning peptide library revealed a consensus sequence with a strict requirement for Arg residues at positions -3 and/or -2 , and allowed for the design of an optimal LMTK3 peptide substrate, Ser as the phospho-acceptor site [51]. The authors claim that a similar approach using a Tyr residue as a phospho-acceptor site would be worth exploring, as LMTK3 is predicted in silico to have dual phospho-specificity (serine/threonine and tyrosine). Because of these different findings, the name Lemur Tyrosine Kinase does not precisely reflect the kinase property of this family of proteins and might be substituted with Lemur Tail Kinase, as suggested by some authors [54].

To highlight the correlations between LMTKs, we extracted the information regarding their residues involved in ATP binding/orienting and in the phospho-transfer reaction, together with the different protein and gene names of the three LMTKs from the UniProt Knowledgebase (UniProtKB) database [55]; these core data are listed in Table 1.

\subsection{Localisation, Membrane Topology and Structural Features of LMTKs}

According to The Human Protein Atlas, LMTK2 is almost ubiquitously expressed in human tissues, with evidence at protein level, while LMTK1 is and LMTK3 are expressed in many tissues, with evidence at protein level only in some of them [56]. LMTK2 and LMTK3 are predominantly anchored to cytoplasmic endo-membranes, although they were also detected in the nucleus [57]. 
Table 1. LMTKs core data ${ }^{1}$ extracted from the UniProt Knowledgebase database.

\begin{tabular}{|c|c|c|c|c|c|c|}
\hline Entry Name & Protein Names & Gene Names & $\begin{array}{l}\text { Length } \\
\text { (Res.) }\end{array}$ & $\begin{array}{l}\text { Proton } \\
\text { Acceptor } \\
\text { Active Site }\end{array}$ & $\begin{array}{c}\text { ATP } \\
\text { Binding } \\
\text { Site }\end{array}$ & $\begin{array}{c}\text { ATP } \\
\text { Nucleotide } \\
\text { Binding (Res. } \\
\text { Number) }\end{array}$ \\
\hline LMTK1_HUMAN & $\begin{array}{l}\text { Serine/threonine-protein kinase LMTK1, (EC } \\
\text { 2.7.11.1) (Apoptosis-associated tyrosine } \\
\text { kinase) (AATYK) (Brain apoptosis-associated } \\
\text { tyrosine kinase) (CDK5-binding protein) } \\
\text { (Lemur tyrosine kinase 1) (p35-binding } \\
\text { protein) (p35BP) }\end{array}$ & $\begin{array}{l}\text { AATK, } \\
\text { AATYK, } \\
\text { KIAA0641, } \\
\text { LMR1, } \\
\text { LMTK1 }\end{array}$ & 1374 & D253 & K156 & 131-139 \\
\hline LMTK2_HUMAN & $\begin{array}{l}\text { Serine/threonine-protein kinase LMTK2, (EC } \\
\text { 2.7.11.1) (Apoptosis-associated tyrosine } \\
\text { kinase 2) (Brain-enriched kinase) (hBREK) } \\
\text { (CDK5/p35-regulated kinase) (CPRK) } \\
\text { (Kinase/phosphatase/inhibitor 2) (Lemur } \\
\text { tyrosine kinase 2) (Serine/threonine-protein } \\
\text { kinase KPI-2) }\end{array}$ & $\begin{array}{l}\text { LMTK2, } \\
\text { AATYK2, } \\
\text { BREK, } \\
\text { KIAA1079, } \\
\text { KPI2, LMR2 }\end{array}$ & 1503 & D265 & K168 & 143-151 \\
\hline LMTK3_HUMAN & $\begin{array}{l}\text { Serine/threonine-protein kinase LMTK3 (EC } \\
\text { 2.7.11.1) (Lemur tyrosine kinase 3) }\end{array}$ & $\begin{array}{l}\text { LMTK3, } \\
\text { KIAA1883, } \\
\text { TYKLM3 }\end{array}$ & 1460 & D266 & K164 & 139-147 \\
\hline
\end{tabular}

${ }^{1}$ Data were obtained by entering the search terms "Human Lemur Tyrosine Kinase" and filtering by those that were reviewed, i.e., by selecting the records with information extracted from the literature and curator-evaluated computational analysis.

LMTK proteins share an overall structure made of a N-terminal signal peptide, a transmembrane domain comprising one or two transmembrane elements, a highly conserved kinase domain, and a long C-terminal tail, reminiscent of the long tail of Lemurs [16]. Originally, the determination of the membrane topology was performed with LMTK2. Briefly, in fluorescence protease protection assays and by using Human Embryonic Kidney cells (HEK293 cells) transfected with LMTK2 tagged with GFP at either the $-\mathrm{NH}_{3}{ }^{+}$or $-\mathrm{COO}^{-}$ terminus, LMTK2 was proved to be an integral membrane protein in which both the amino and carboxyl termini are exposed to the cytoplasm. This topology also locates the kinase active site within the cytoplasm [16,58].

Similar studies have not been performed with LMTK1 and LMTK3; therefore, their membrane topology can only be predicted on the basis of available data $[55,59]$. As an example, Figure 1 shows the protein sequence, the transmembrane topology, and the annotations of LMTK3 extracted from UniProtKB; data were processed using the Protter web-based tool (http:/ / wlab.ethz.ch/protter) [59] to produce the topology plot and orientation of LMTK3 (Figure 1). Figure 1a,b highlight: 1. the transmembrane region with a unique transmembrane element; 2 . the conserved kinase domain, comprising the ATP binding region, the ATP binding site, and the proton acceptor active site (Table 1); 3 . the long C-terminal tail domain that constitutes the largest segment of the protein structure; 4. the cytoplasmatic localisation of both the kinase domain and the C-tail domain. The three-dimensional structure of the kinase domain of LMTK3 (Figure 1c) was retrieved from the SWISS MODEL Database (protein ID: 6seq.1). To date, this is the only domain of LMTKs whose structure has been solved (at 2.1- $\AA$ resolution), using X-ray diffraction and by studying a recombinant protein comprising the residues 134 to 444 [51]. The structure of the LMTK3 kinase domain shares structural and sequence similarities to different kinase domains, such as those of the transmembrane receptor epidermal growth factor receptor (EGFR), insulin receptor (INSR), and Janus kinase (JAK) [51]. This structural achievement is fundamental for further structural/functional studies and for facilitating the structurebased design of inhibitors that could help in the dissection of the signalling pathways in which LMTK3 is involved. 


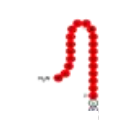

(a)

EXTRA

\section{HUMAN LMTK3}
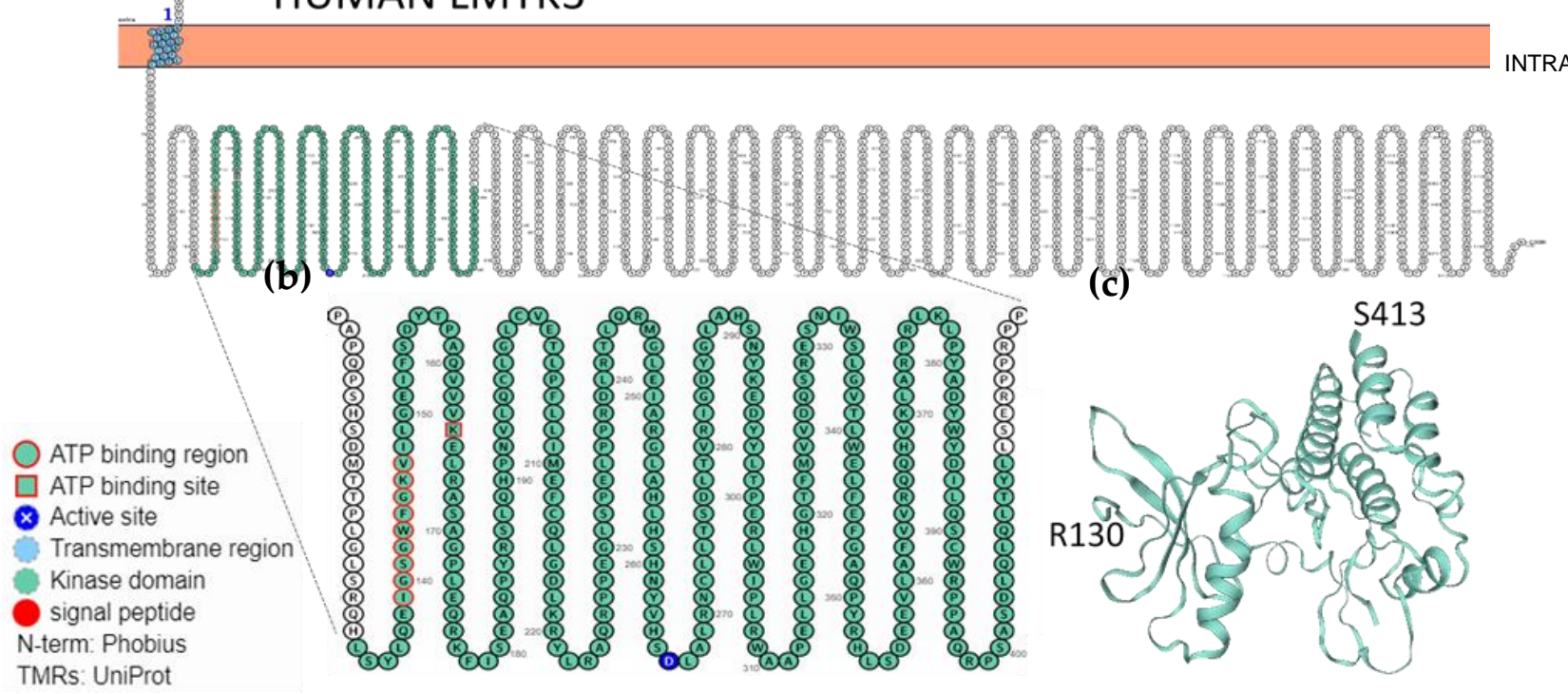

Figure 1. Sequence, predicted transmembrane topology, and kinase domain of human LMTK3. (a) Topology plot visualising the N-terminal signal peptide, the transmembrane region (blue), and the kinase domain (green), followed by the C-terminal tail domain. (b) An enlarged view of the catalytic kinase domain, evidencing the functional annotations associated with LMTK3_HUMAN UniProtKB entry and listed in the flanking legend. N-terminus location is predicted by Phobius server, while transmembrane regions (TMR) are derived from UniProt annotation. (c) Three-dimensional structure of the kinase domain, as displayed in SWISS MODEL Database (protein ID: 6seq.1).

\section{Literature Review}

\subsection{Evidence for LMTK2 Involvement in Prostate Cancer}

Gene expression analysis was used to investigate the potential association of LMTK2 with the development of PCa in two different studies [60,61] (Table 2). The first study evaluated the expression of $7 \mathrm{PCa}$ candidate genes in cancer versus benign prostatic hyperplasia $(\mathrm{BPH})$ samples, in correlation with genotype at risk variants identified by genome-wide association studies (GWAS) [60]. The data confirm that the risk genotype at the GWAS variant rs6465657 correlates with LMTK2 expression and that prostate adenocarcinoma samples expresses $68 \%$ less LMTK2 mRNA than BPH samples, providing strong evidence for the role of this gene in PCa progression. The second study examined the expression level of LMTK2 in blood samples of prostate cancer patients, with the aim of making use of LMTK2 level as a potential biomarker for stratification between clinically insignificant and clinically significant PCa patients [61]. LMTK2 expression significantly decreases in blood samples of patients with PCa versus BPH as compared to control (with high PSA but no PCa), while PSA density value (ng/mL, based on PSA measurement divided by prostate volume) can differentiate $\mathrm{PCa}$ from benign prostate disease. The authors conclude that LMTK2 expression measurement, in conjunction with PSA density value, may assist in the identification of PCa clinical significance.

LMTK2 was reported to interact with different protein partners, originating from a complex interacting network that is relevant in human health and disease $[16,45,54]$. These studies provide details about LMTK2 interaction partners, as summarised below.

Androgen Receptor (AR) is a member of the steroid hormone nuclear receptor family and a ligand-dependent nuclear transcription factor that mediates the effects of androgens (Figure 2). AR controls prostate development and maintenance [62] and plays a key role in the development and progression of PCa $[63,64]$. As demonstrated by Shah and colleague 
(Table 2) [57], 1. LMTK2 and AR interact in prostate cancer epithelial cells and colocalise in human prostate tissue, and 2. in model cell lines, LMTK2 was discovered to be a negative regulator of AR transcriptional activity. In LNCaP cell line, LMTK2/AR complexes are predominantly extra-nuclear, but, in the presence of androgens, they localise in the nuclei. The study also shows that a decrease in LMTK2 expression is associated with increased risk of PCa and hyperplasia. Moreover, LMTK2 down-regulation obtained in PCa LNCaP cell line promotes tumour-forming capacity and proliferation, suggesting that the decrease in LMTK2 expression in PCa patients may promote tumour cells' proliferation by enhancing AR transcriptional activity. Lastly, FKBP51, an AR-dependent gene and a positive regulator of AR activity, is highly expressed in castrate resistant $\mathrm{PCa}$ (CRPC) when compared with primary tumours. Accordingly, in LMTK2-KD PCa cells deprived of androgen FKBP51, expression becomes intensified, together with the mRNA levels of AR-dependent genes. This is a relevant piece of evidence that links LMTK2 to pathogenesis and progression of $\mathrm{PCa}$ to the castration-resistant phase.

Myosin VI is an actin-based motor protein involved in intracellular vesicular endocytic trafficking. Its expression is up-regulated in human PCa [65]. In LNCaP cells, in which myosin VI is also overexpressed, it is localised to early endosomes, recycling endosomes and trans-Golgi network (Table 2) [66]. It is also involved in the secretion of prostatespecific antigen (PSA) and vascular endothelial growth factor (VEGF), both supporting $\mathrm{PCa}$ growth. Interestingly, intracellular targeting experiments showed that Myosin VI interacts with, and coimmunoprecipitates with, LMTK2. Since both proteins participate in recycling endosome pathway and have a role in cancer progression, the authors emphasise the relevance of the secretory pathway by the recycling endosome to PCa pathogenesis.

Lastly, it has been recognised that LMTK2 also modulates the function of kinesin1 molecular motor (Table 2) [67]. In fact, in HeLa cells, LMTK2 interacts with Protein Phosphatase-1C (PP1C) and induces its inhibitory phosphorylation, thus increasing inhibitory phosphorylation of the substrate Glycogen Synthase Kinase-3 $\beta$ (GSK3 $\beta$ ). This inhibition 1. reduces Kinesin-1-Light Chain 2 (KLC2) phosphorylation, and 2. promotes KLC2 binding of Smad 2 cargo and its transport to the nucleus mediated by Kinesin 1 . This mechanism triggers the Smad2 signalling, induced by the Transforming Growth Factor- $\beta$ (TGF- $\beta$ ) receptor stimulation. The reduction of LMTK2 expression by small interfering RNA (siRNA), mimicking the LMTK2 deficiency typical of PCa [57], reduced the binding of Smad2 to KLC2 and the downstream signalling. Therefore, since LMTK2 expression is significantly reduced in PCa tissues, Smad2 binding to KLC2 and transport on Kinesin-1 may also be inhibited in PCa cells.

Table 2. Evidence from literature for LMTK2 involvement in prostate cancer.

\begin{tabular}{|c|c|c|c|c|}
\hline Reference & Cell Line/Tissue & Principal Techniques & Main Results & Conclusions \\
\hline \multirow[t]{2}{*}{$\begin{array}{l}\text { Harries } \\
\text { et al. [60] }\end{array}$} & $\begin{array}{l}\text { Human prostate samples } \\
\text { (cancer and benign } \\
\text { prostatic hyperplasia, } \\
\text { BPH) from Exeter tissue } \\
\text { bank }\end{array}$ & $\begin{array}{l}\text { PCR amplification and } \\
\text { sequencing for } \\
\text { genotyping } 7 \text { GWAS } \\
\text { risk loci }\end{array}$ & $\begin{array}{l}\text { Risk genotype at the GWAS variant } \\
\text { rs6465657 correlates with LMTK2 } \\
\text { expression }\end{array}$ & \multirow{2}{*}{$\begin{array}{l}\text { Expression levels of LMTK2 } \\
\text { inversely correlate with the } \\
\text { presence of prostate cancer }\end{array}$} \\
\hline & & Real-time PCR & $\begin{array}{l}\text { Prostate adenocarcinoma samples } \\
\text { expressed } 68 \% \text { less LMTK2 mRNA than } \\
\text { BPH samples }\end{array}$ & \\
\hline $\begin{array}{l}\text { Vezelis } \\
\text { et al. [61] }\end{array}$ & $\begin{array}{l}\text { Blood sample of patients } \\
\text { who had rising PSA after } \\
\text { negative transrectal } \\
\text { systematic prostate biopsy }\end{array}$ & $\begin{array}{l}\text { Analysis of CRISP3, } \\
\text { LMTK2 and MSMB } \\
\text { gene expression by } \\
\text { means of quantitative } \\
\text { RT-PCR }\end{array}$ & $\begin{array}{l}\text { LMTK2 and MSMB expression } \\
\text { significantly decreases in blood samples } \\
\text { of patients with PCa and Benign Prostate } \\
\text { Disease as compared to control } \\
\text { PSA density }(\mathrm{ng} / \mathrm{mL}) \text { can differentiate } \\
\text { PCa from the benign prostate disease }\end{array}$ & $\begin{array}{l}\text { PSA density, in combination } \\
\text { with LMTK2 expression level, } \\
\text { may assist in stratification } \\
\text { between clinically insignificant } \\
\text { and clinically significant PCa }\end{array}$ \\
\hline
\end{tabular}


Table 2. Cont.

\begin{tabular}{|c|c|c|c|c|}
\hline \multirow{5}{*}{$\begin{array}{l}\text { Shah et al. } \\
\text { [57] }\end{array}$} & $\begin{array}{l}\text { Human prostate tissue } \\
\text { array (prostate cancer, } \\
\text { hyperplasia, and normal } \\
\text { prostate tissue) }\end{array}$ & $\begin{array}{l}\text { Immunostaining } \\
\text { analysis }\end{array}$ & LMTK2 is down regulated in human PCa & \multirow{5}{*}{$\begin{array}{l}\text { Loss of LMTK2 protein is } \\
\text { strongly associated with prostate } \\
\text { cancer and prostate hyperplasia } \\
\text { LMTK2 interacts directly with } \\
\text { AR and inhibits its } \\
\text { transcriptional activity } \\
\text { LMTK2 down-regulation } \\
\text { promotes tumour forming } \\
\text { capacity and proliferation } \\
\text { The decrease in LMTK2 } \\
\text { expression in prostate cancer } \\
\text { patient may promote tumour } \\
\text { cells proliferation by enhancing } \\
\text { AR transcriptional activity }\end{array}$} \\
\hline & $\begin{array}{l}\text { LNCaP cells } \\
\text { Normal human prostate } \\
\text { tissue }\end{array}$ & $\begin{array}{l}\text { Coimmunoprecipitation } \\
\text { Colocalisation } \\
\text { analysis by } \\
\text { immunostaining }\end{array}$ & $\begin{array}{l}\text { LMTK2 and AR interact in prostate } \\
\text { cancer cells and colocalise in human } \\
\text { prostate tissue }\end{array}$ & \\
\hline & HEK293 cells & $\begin{array}{l}\text { Dual luciferase assay } \\
\text { with } L M T K 2 \\
\text { knockdown or } L M T K 2 \\
\text { overexpression }\end{array}$ & $\begin{array}{l}\text { Knockdown of } L M T K 2 \text { in cells expressing } \\
\text { AR enhances androgen-dependent } \\
\text { activation of a luciferase reporter gene } \\
\text { Overexpression of } L M T K 2 \text { in cells } \\
\text { expressing AR decreases } \\
\text { androgen-dependent activation of a } \\
\text { luciferase reporter gene }\end{array}$ & \\
\hline & LNCaP cells & Real-time PCR & $\begin{array}{l}\text { LMTK2 knockdown cells, deprived from } \\
\text { androgens, show a significant increase in } \\
\text { mRNA expression of AR responsive } \\
\text { genes }\end{array}$ & \\
\hline & LNCaP cells & $\begin{array}{l}\text { Tumoursphere assay } \\
\text { Cell viability assay }\end{array}$ & $\begin{array}{l}\text { LNCaP knockdown cells: } \\
\text {-showed higher colony-forming capacity } \\
\text {-showed } \sim 5 \text { times higher cell viability } \\
\text { under androgen } \\
\text { starvation }\end{array}$ & \\
\hline \multirow{3}{*}{$\begin{array}{l}\text { Puri et al. } \\
\text { [66] }\end{array}$} & \multirow{3}{*}{ LNCaP cells } & $\begin{array}{l}\text { Immunofluorescence } \\
\text { microscopy }\end{array}$ & $\begin{array}{l}\text { Myosin VI is present on early endosomes, } \\
\text { recycling endosomes and trans-Golgi } \\
\text { network }\end{array}$ & \multirow{3}{*}{$\begin{array}{l}\text { LMTK2, together with Myosin } \\
\text { VI, may participate in the } \\
\text { orchestration of endosomal } \\
\text { recycling pathway } \\
\text { The secretory pathway via the } \\
\text { recycling endosome can be } \\
\text { involved in PCa pathology }\end{array}$} \\
\hline & & Coimmunoprecipitation & $\begin{array}{l}\text { LMTK2 binds to and } \\
\text { coimmunoprecipitates with Myosin VI }\end{array}$ & \\
\hline & & $\begin{array}{l}\text { Myosin VI siRNA } \\
\text { knockdown }\end{array}$ & $\begin{array}{l}\text { Secretion of PSA and VEGF } \\
\text { is reduced }\end{array}$ & \\
\hline \multirow[t]{2}{*}{$\begin{array}{l}\text { Manser } \\
\text { et al. [67] }\end{array}$} & \multirow[t]{2}{*}{ HeLa cells } & $\begin{array}{l}\text { Coimmunoprecipitation } \\
\text { Immunoblot analysis }\end{array}$ & $\begin{array}{l}\text { LMTK2 interacts with Protein } \\
\text { Phosphatase-1C } \\
\text { LMTK2 increases inhibitory } \\
\text { phosphorylation of Glycogen Synthase } \\
\text { Kinase-3 } \beta \\
\text { LMTK2 reduces Kinesin-1-Light Chain } 2 \\
\text { phosphorylation and promotes KLC2 } \\
\text { binding of Smad2 transcription factor }\end{array}$ & \multirow[t]{2}{*}{$\begin{array}{l}\text { Since LMTK2 expression is } \\
\text { significantly reduced in prostate } \\
\text { cancer tissues, Smad2 binding to } \\
\text { KLC2 and transport on Kinesin-1 } \\
\text { may also be inhibited in prostate } \\
\text { cancer cells }\end{array}$} \\
\hline & & $\begin{array}{l}\text { siRNA knockdown of } \\
\text { LMTK2 }\end{array}$ & $\begin{array}{l}\text { LMTK2 knockdown inhibits Smad2 } \\
\text { nuclear signalling in response to TGF- } \beta \\
\text { receptor activation }\end{array}$ & \\
\hline
\end{tabular}

AR, androgen receptor; PSA, prostate-specific antigene; VEGF, vascular endothelial growth factor; TGF- $\beta$, Transforming Growth Factor- $\beta$; GWAS, genome wide association studies (for prostate cancer); CRISP3, cysteine rich secretory protein 3; MSMB, microseminoprotein beta.

\subsection{Evidence for LMTK3 Involvement in Prostate Cancer}

Two of the articles included in our review investigate the role of LMTK3 in PCa. The experiments of Sun and colleagues (Table 3) were performed in human PCa tissue as well as in two cell model systems: 1 . PC3 and LNCaP cell lines; and 2. a transplant tumour model in nude mice, generated with PC3 cells infected with a recombinant lentivirusLMTK3 construct [68]. The expression of LMTK3 appeared to be significantly reduced in cancer specimens compared to adjacent normal tissue. Instead, overexpression of LMTK3 in cancer cell lines decreased cell viability and migratory potential, also inducing apoptosis. In xenografts, this approach inhibited tumorigenicity of infected PC 3 cells and induced apoptosis in vivo. Altered expression of apoptosis-related proteins Bcl-2, Bax and Caspase- 3 in vitro and in vivo confirmed that the tumour suppression effect of LMTK-3 was mediated by modulating cell apoptosis. These findings suggest that LMTK3 may be a promising target for PCa therapy because of its potential and specific effect on PCa cell growth and apoptosis. 


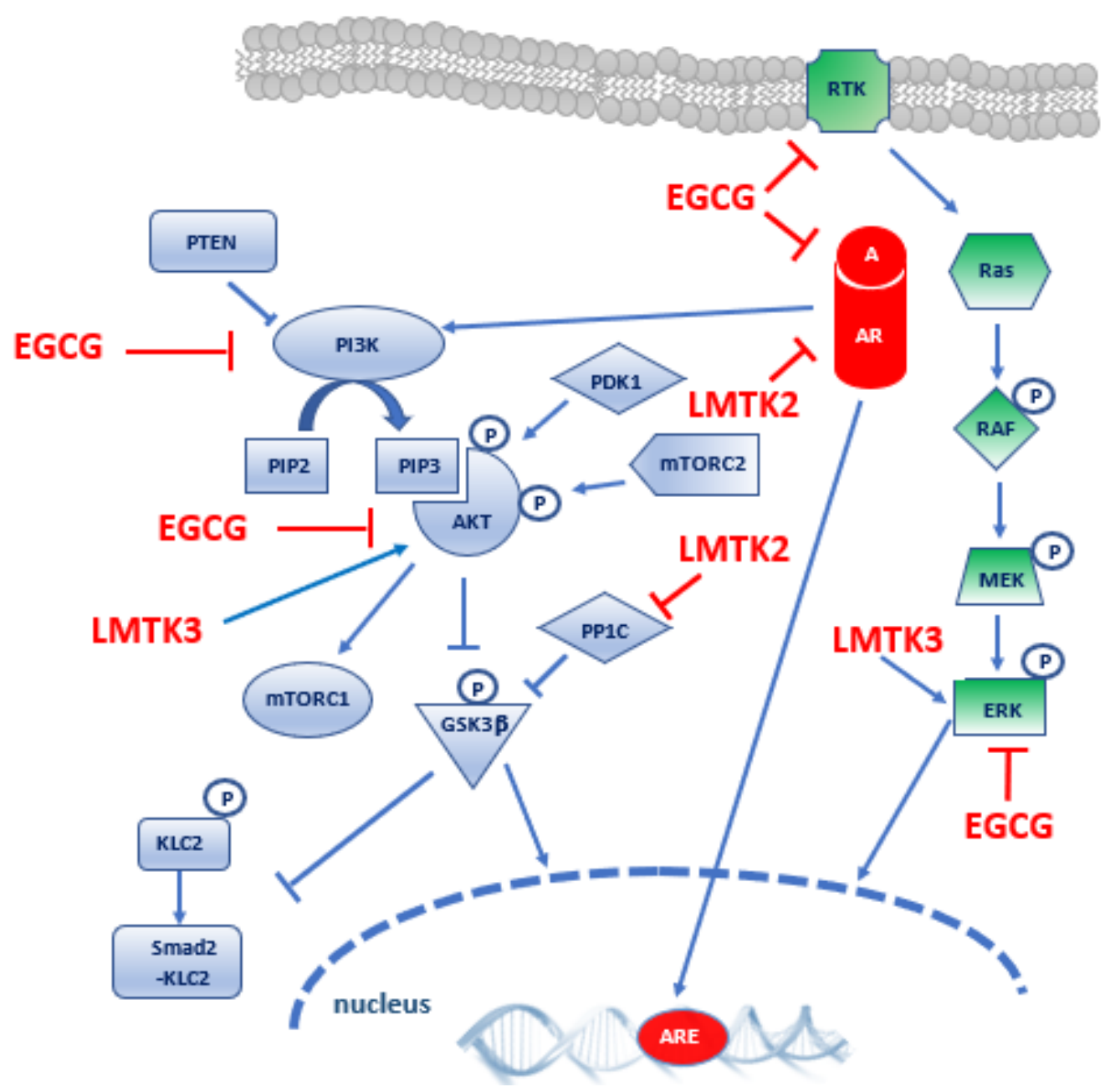

Figure 2. A simplified scheme of PI3K-Akt-mTOR signalling interaction with AR and RTK pathways. The image displays a model of PI3K-Akt-mTOR signalling via Class IA PI3Ks and crosstalk with AR and Ras/MAPK signalling cascades. Blue, red, and green objects represent PI3K-Akt-mTOR, AR and RTK signalling molecules, respectively. Inhibition arrows are red, activation arrows are blue, and the (P) symbol indicates phosphorylation. Details on EGCG, LMTK2 and LMTK3 effects are provided in the text. A, androgen; Akt, protein kinase $\mathrm{B} ; \mathrm{AR}$, androgen receptor; $\mathrm{ARE}$, androgen responsive element; EGCG, epigallocatechin-3-gallate; ERK, extracellular signal regulated kinases 1 and 2; GSK3 $\beta$, glycogen synthase kinase 3 beta; KLC2, Kinesin-1-Light Chain 2; MEK, mitogen-activated protein kinase kinase; mTOR, mammalian target of rapamycin; mTORC1/2, mTOR complex 1/2; PDK1, phosphoinositide dependent kinase 1; PI3K, phosphatidylinositol 3-kinase; PIP2, phosphatidylinositol 4,5-bisphosphate; PIP3, phosphatidylinositol (3,4,5)-trisphosphate; PTEN, Phosphatase and TENsin homolog; PP1C, protein phosphates 1C; RAF, rapidly accelerated fibrosarcoma; RAS homolog enriched in brain; RTK, receptor tyrosine kinase; Smad2, mothers against decapentaplegic homolog 2.

The three most important subfamilies of MAPKs (extracellular signal regulated kinases 1 and 2 [ERK1/2], c-Jun NH2-terminal kinase [JNK], and p38 mitogen-activated protein) and the cell signalling cascade of the phosphatidylinositol 3-kinase/protein kinase$\mathrm{B}$ (PI3K/Akt) are known to play a key role in cell growth, differentiation, and apoptosis and can be activated in many different cancers. In accordance with this, the aforementioned data also demonstrate that, in PC3 cells and xenografts, the PI3K/Akt and MAPK signalling pathways may contribute to LMTK3 induced apoptosis. In fact, after LMTK3 overexpression, phosphorylation of Akt and ERK was inhibited, while phosphorylation and activation of p38 kinase and JNK were induced. 
Table 3. Evidence from the literature for LMTK3 involvement in prostate cancer.

\begin{tabular}{|c|c|c|c|c|}
\hline Reference & Cell Line/Tissue & Principal Techniques & Main Results & Conclusions \\
\hline \multirow{3}{*}{ Sun et al. [68] } & Prostate cancer tissue & $\begin{array}{l}\text { Quantitative RT-PCR } \\
\text { Immunoblot analysis } \\
\text { data }\end{array}$ & $\begin{array}{l}\text { Expression of LMTK3 is reduced } \\
\text { as compared to normal tissue }\end{array}$ & \multirow{3}{*}{$\begin{array}{l}\text { A low level of LMTK3 } \\
\text { expression is associated } \\
\text { with PCa } \\
\text { LMTK3 overexpression } \\
\text { can induce PCa } \\
\text { apoptosis in vitro and } \\
\text { in vivo, and Akt and } \\
\text { MAPK signalling } \\
\text { pathways may } \\
\text { contribute to this } \\
\text { process } \\
\text { Low levels of LMTK3 } \\
\text { ex-pression in PCa } \\
\text { tissue may reflect a } \\
\text { decreased apoptotic } \\
\text { rate }\end{array}$} \\
\hline & $\begin{array}{l}\text { PC3 and LNCaP } \\
\text { prostate cancer cells } \\
\text { infected with } \\
\text { recombinant } \\
\text { lentivirus-LMTK3 }\end{array}$ & $\begin{array}{l}\text { MTT and TUNEL } \\
\text { assays } \\
\text { Transwell and Matrigel } \\
\text { invasion assays } \\
\text { Immunoblot analysis }\end{array}$ & $\begin{array}{l}\text { Overexpression of LMTK3: } \\
-\quad \text { decreases cell viability and } \\
\text { induces apoptosis } \\
-\quad \text { attenuates cell invasion } \\
\text { and migration ability } \\
-\quad \text { inhibits phosphorylation of } \\
\text { Akt and ERK, and } \\
\text { promotes phosphorylation } \\
\text { of p38 kinase and JNK in } \\
\text { PC3 cells }\end{array}$ & \\
\hline & $\begin{array}{l}\text { Subcutaneous tumour } \\
\text { model in nude mice, } \\
\text { based on PC } 3 \text { cells } \\
\text { infected with } \\
\text { recombinant } \\
\text { lentivirus-LMTK3 }\end{array}$ & $\begin{array}{l}\text { Caliper measurement } \\
\text { TUNEL assay } \\
\text { Immunoblot analysis }\end{array}$ & $\begin{array}{l}\text { Overexpression of LMTK3: } \\
-\quad \text { decreases tumour volume } \\
-\quad \text { increases \% of apoptotic } \\
\text { cells } \\
-\quad \text { inhibits phosphorylation of } \\
\text { Akt and ERK; and } \\
\text { promotes phosphorylation } \\
\text { of p38 kinase and JNK in } \\
\text { xenografts }\end{array}$ & \\
\hline Gao et al. [70] & $\begin{array}{l}\text { DU145 prostate cancer } \\
\text { cells }\end{array}$ & $\begin{array}{l}\text { Reverse transfection } \\
\text { with a kinase siRNA } \\
\text { library } \\
\text { Exposition to IGFIR1 } \\
\text { AZ12253801 inhibitor }\end{array}$ & $\begin{array}{l}\text { AZ12253801 inhibits IGFIR } \\
\text { phosphorylation and cell } \\
\text { viability } \\
\text { LMTK3 depletion enhances } \\
\text { AZ12253801 sensitivity }\end{array}$ & $\begin{array}{l}\text { LMTK3 is among the } \\
\text { putative mediators of } \\
\text { resistance to IGFIR } \\
\text { inhibition }\end{array}$ \\
\hline
\end{tabular}

IGFIR, insulin-like growth factor I receptor (receptor tyrosine kinase).

The rationale for these findings can be found in the coactivation of the RAS/MAPK and PI3K-Akt-mTOR signalling pathways, frequently occurring in human malignancies, including $\mathrm{PCa}$ (Figure 2). Indeed, a complex crosstalk between the two signalling cascades promotes PCa growth and metastasis [69].

Insulin-like growth factor 1 receptor (IGFIR) is a Receptor Tyrosine Kinase (RTK) driving cell proliferation, invasion, and survival. In the study of Gao and colleagues (Table 3), DU145 PCa cells were reverse-transfected using a kinase siRNA library and exposed to IGFIR AZ12253801 inhibitor to identify proteins that influence the viability response to the inhibitor [46]. LMTK3 depletion enhanced AZ12253801 sensitivity, suggesting that LMTK3 may be a candidate resistance mediator with roles in regulating receptor (or post receptor) signalling, thus confirming its role in the complex signalling cascade of IGFIR.

\section{Epigallocatechin-3-Gallate}

The overall incidence of PCa is lower in Asian countries compared to Western Countries, but the risk increases by nearly 20-fold for Asian immigrants living in the United States. This effect seems to be related to the adoption of a Western lifestyle, which contemplates lower intakes of vegetables, fruits, fish, tea, and soy, at the expense of increased consumption of meat and fatty food [71,72].

Natural bioactive compounds are molecules derived from plants and other natural sources which may exert health benefits. Bioactive compounds such as curcumin, lycopene, and green tea catechins have raised the interest of the scientific community because of their protective effect against cancer onset and progression [72-74]. Among 
them, Epigallocatechin-3-gallate (EGCG) is the main constituent of brewed green tea and polyphenol dried extract, as well as the most biologically active. Green tea extracts and its polyphenols, also known as catechins, are studied for their anti-cancer and chemopreventive effects on several cancer models, including PCa [75-81]. Multiple mechanisms mediate the effect of EGCG on PCa [82]. EGCG was shown to impact the same signalling pathways affected by LMTKs, such as PI3K/Akt/mTOR and MEK/ERK, as described in the "Discussion" section (Figure 2). In fact, EGCG is a competitive inhibitor of the class I PI3K and prevents the initial phosphorylation of Akt, necessary for the progression through the cell cycle. Moreover, EGCG inhibits mTOR and interferes with the signalling cascade downstream from mTOR, promoting the reactivation of apoptosis [83]. Furthermore, EGCG administration causes growth arrest and apoptosis thorough a decrease in ERK phosphorylation and an increase in JNK and p38 phosphorylation in human pancreatic cancer cells [84].

Moreover, EGCG induces the inactivation of AR-mediated transcription through its inhibitory action on histone acetyltransferase activity, which is necessary for the activation of AR transcription factors [85]. EGCG is also a direct small-molecule inhibitor of IGFIR activity in various cancer cell lines, resulting in the inhibition of cell proliferation and transformation [86].

The wide spectrum of effects exerted by EGCG is also mediated by its capacity to disrupt tightly packed and high-ordered membrane structures called lipid rafts that are involved in the regulation of cellular signalling. Lipid rafts are rich in RTKs, and these receptors are inhibited by EGCG in many cancer models [75].

\section{Discussion}

Despite the enormous progress made in the diagnosis and treatment of PCa, this pathology continues to be not only the second most diagnosed oncologic disease, but also one of the leading causes of cancer death in men worldwide. Most PCas require androgens to grow, which is why androgenic deprivation (ADT) is used as standard therapy to rescue the patient. ADT leads to the temporary inhibition of AR. Activated $\mathrm{AR}$ is a transcription factor of paramount importance for the regulation of cell growth, differentiation, migration, and survival in all androgen-dependent tissues. In prostate tissue, activated AR modulates the development of the gland, tissue homeostasis, and cell transformation. However, too often the clinical response to ADT is only temporary, since patients almost inevitably develop resistance to therapy over time. At that point, ADT becomes only palliative, though it still ameliorates the quality of life of patients. Because of the genetic and phenotypic heterogeneity of $\mathrm{PCa}$, it is now very difficult to distinguish indolent tumours from aggressive ones. This makes prognosis, and personal treatment, rather difficult to achieve. The challenge that scientists face today is that of achieving a better risk stratification of PCa to reduce under-diagnosis, unnecessary biopsy, or overtreatment in order to enable clinicians to identify the optimal personalised therapeutic plan for each patient. Scientific research has long been committed to the development of a solid predictive genetic signature for better stratification of patients diagnosed with PCa [87-89], but more work needs to be done. Nevertheless, the advent of GWAS studies has given new impetus to the investigations on PCa carcinogenesis and the potential involvement of specific genes in the process of prostate cell transformation.

As evidenced in the present review, LMTK2 and LMTK3 are involved in PCa development. Their level of expression appears to be reduced in human prostate tissue as compared to normal tissue $[57,60,68]$. Additionally, LMTK2 blood level has been shown to contribute to the identification of clinically significant PCa [61]. We report that both LMTK2 and LMTK3 interact with, and modulate, the activity of specific enzymes of the signalling cascades regulating cell growth, differentiation, and apoptosis in PCa cells. LMTK interacting partners are involved in PI3K/Akt and Ras/MAPK signalling cascades, which are frequently coactivated in human malignancies, including PCa and CRPC [69]. 
In PCa cell lines, LMTK3 overexpression increased the levels of phosphorylated p38 and JNK, two MAPKs that mediate apoptotic death, and decreased ERK1/2 and Akt phosphorylation [68]. In this way, LMTK3 acts as a tumour suppressor that regulates cell apoptosis, modulating the level of anti-apoptotic Bcl-2 and decreasing pro-apoptotic Bax and caspase-3. Therefore, the low levels of LMTK3 found in PCa tissue may be associated with a decreased apoptotic rate of cancer cells.

A direct interaction between AR and LMTK2 and its involvement in the translocation of AR to the nucleus has been speculated after the discovery of the LMTK2-AR complex localisation in the nuclear fraction of PCa cells [64]. Notably, AR signalling axis converges with RAS/MAPK and PI3K-Akt-mTOR to promote PCa development (Figure 2); in fact, AR signalling regulates cell growth, differentiation, and survival, thus playing a critical role as a transcriptional regulator in prostate tissue homeostasis and in PCa [69], while $\mathrm{PI} 3 \mathrm{~K} / \mathrm{Akt} / \mathrm{mTOR}$ and Ras/MAPK signalling favours epithelial-mesenchymal transition and cell migration/invasion [90].

Since PI3K-Akt-mTOR pathway appears to be frequently activated in many aggressive $\mathrm{PCa}$, targeting this pathway constitutes a valuable opportunity in PCa treatment. A better understanding of the dynamics of the three interacting signalling pathways is needed to design new therapeutic approaches based on combining the inhibition of PI3K/Akt/mTOR pathway with the inhibition of either the Ras/MAPK or AR signalling pathways $[69,91]$.

In this scenario, LMTKs represent valid and promising therapeutic targets in PCa management, since their overexpression is expected to modify the complex signalling network involving PI3K/Akt/mTOR, RAS/MAPK and AR pathways. Despite the large number of compounds tested in vitro as specific inhibitors able to target different members of these signalling cascades, many of them did not reach the phase II of clinical trials. The reason for this failure can be found in the intense relationships and crosstalk between these signalling pathways, allowing for a compensatory response to the candidate drug effect, thus making the treatment ineffective [92].

Since PCa treated with ADT eventually switch to an androgen refractory state, where cells express survival genes bypassing hormone-dependent AR recruitment, myosin VI has been suggested as a potential therapeutic target for PCa, given that it acts as a regulator element able to interact with AR and affect AR-dependent protein levels. In this regard, LMTK2 is known to bind directly to myosin VI in human cervical cancer HeLa cells, permitting the delivery of membrane pumps, channels, and nutrient receptors from the early endosome to the perinuclear endocytic recycling compartment (ERC) and to the plasma membrane [93]. Moreover, LMTK2 has been discovered to be related to the secretory pathway via the recycling endosome and to Smad2 transcription factor transport to the nucleus following TGF- $\beta$ stimulation. This is demonstrated by the interaction of LMTK2 with two different molecular motors, myosin VI and kinesin-1, respectively [66,67]. Moreover, given these findings, we predict that the modulation of LMTK2 levels or activity may also have an important impact on these two molecular motors with expected important alterations in PCa cells.

The development and characterisation of specific modulators of LMTKs expression is a promising field of research. Interestingly, the treatment with the synthetic Protein Kinase C (PKC) activator tetradecanoylphorbol-13-acetate (TPA) in mouse embryonic fibroblast cells (NIH 3T3) increases the protein levels of LMTK2 through the binding of activator protein-1 (AP-1) transcription factor complex to LMTK2 promoter and the consequent increase of mRNA production and LMTK2 synthesis [94]. The coadministration of TPA and EGCG in cancer model systems might be a promising approach to promote both the synergic inhibition of AR signalling mediated by the LMTK2 inhibitory action and the down regulation of PI3K-Akt-mTOR pathway directly by means of EGCG.

In conclusion, the identification of regulators of expression and/or activity of LMTKs are of high clinical relevance for the design of novel PCa treatment strategies. We speculate that such LMTKs effectors might exert a synergistic antitumor action with EGCG, a natural 
plant-derived polyphenolic compound with known chemopreventive and anticancer effects on prostate cancer cells.

\section{Methods: Search Strategy and Study Selection}

The studies included in this review were research articles reporting on LMTK involvement in PCa. References were obtained by searching Pubmed, Scopus, and WoS databases. In all the databases considered, the search term Lemur Tyrosine Kinase was used alone and in association with PCa, using and as Boolean operator to combine subjects. The LMTK acronym was also used along with the numbers 1,2 , and 3 , to specify the three structurally and evolutionary related members of this protein kinase family.

The publication date range considered for study selection was January 2005-January 2020, although a literature search performed in March 2021 added a supplemental study [61].

We imported the results of each search into the EndNote ${ }^{\circledR}$ software (Clarivate Analytics) for reference management, merging all records in a single collection. After the elimination of duplicates, two reviewers with biochemical backgrounds performed the eligibility assessment in parallel, without final disagreement. The final collection consisted of seven research articles.

The included studies were obtained as full-text articles and thoroughly examined. For each study, the information relevant to the present revision was extracted and documented in especially designed spreadsheets (Tables 2 and 3), under the following headers: Reference, Cell line/tissue, Principal techniques, Main results, and Conclusions.

Author Contributions: E.F., V.N. and S.B. critically reviewed the literature and wrote the manuscript. All authors have read and agreed to the published version of the manuscript.

Funding: This research received no external funding.

Conflicts of Interest: The authors declare no conflict of interest.

\section{References}

1. Ardito, F.; Giuliani, M.; Perrone, D.; Troiano, G.; Muzio, L. Lo The crucial role of protein phosphorylation in cell signalingand its use as targeted therapy (Review). Int. J. Mol. Med. 2017, 40, 271-280. [CrossRef]

2. Wilson, L.J.; Linley, A.; Hammond, D.E.; Hood, F.E.; Coulson, J.M.; MacEwan, D.J.; Ross, S.J.; Slupsky, J.R.; Smith, P.D.; Eyers, P.A.; et al. New Perspectives, opportunities, and challenges in exploring the human protein kinome. Cancer Res. 2018, 78, 15-29. [CrossRef]

3. Bradley, D.; Beltrao, P. Evolution of protein kinase substrate recognition at the active site. PLoS Biol. 2019, 17, e3000341. [CrossRef]

4. Hanks, S.K. Genomic analysis of the eukaryotic protein kinase superfamily: A perspective. Genome Biol. 2003, 4, 111. [CrossRef]

5. Lemmon, M.A.; Schlessinger, J. Cell signaling by receptor tyrosine kinases. Cell 2010, 141, 1117-1134. [CrossRef]

6. Du, Z.; Lovly, C.M. Mechanisms of receptor tyrosine kinase activation in cancer. Mol. Cancer 2018, 17, 58. [CrossRef]

7. Yamaoka, T.; Kusumoto, S.; Ando, K.; Ohba, M.; Ohmori, T. Receptor tyrosine kinase-targeted cancer therapy. Int. J. Mol. Sci. 2018, 19, 3491. [CrossRef]

8. Esteban-Villarrubia, J.; Soto-Castillo, J.J.; Pozas, J.; Román-Gil, M.S.; Orejana-Martín, I.; Torres-Jiménez, J.; Carrato, A.; AlonsoGordoa, T.; Molina-Cerrillo, J. Tyrosine kinase receptors in oncology. Int. J. Mol. Sci. 2020, 21, 8529. [CrossRef]

9. Pottier, C.; Fresnais, M.; Gilon, M.; Jérusalem, G.; Longuespée, R.; Sounni, N.E. Tyrosine kinase inhibitors in cancer: Breakthrough and challenges of targeted therapy. Cancers 2020, 12, 731. [CrossRef] [PubMed]

10. Roskoski, R. Properties of FDA-approved small molecule protein kinase inhibitors: A 2020 update. Pharm. Res. 2020, 152, 104609. [CrossRef]

11. Liang, Y.; Zhang, T.; Zhang, J. Natural tyrosine kinase inhibitors acting on the epidermal growth factor receptor: Their relevance for cancer therapy. Pharm. Res. 2020, 161, 105164. [CrossRef] [PubMed]

12. Zhao, Y.; Bilal, M.; Raza, A.; Khan, M.I.; Mehmood, S.; Hayat, U.; Hassan, S.T.S.; Iqbal, H.M.N. Tyrosine kinase inhibitors and their unique therapeutic potentialities to combat cancer. Int. J. Biol. Macromol. 2021, 168, 22-37. [CrossRef] [PubMed]

13. Janjigian, Y.Y.; Smit, E.F.; Groen, H.J.M.; Horn, L.; Gettinger, S.; Camidge, D.R.; Riely, G.J.; Wang, B.; Fu, Y.; Chand, V.K.; et al. Dual inhibition of EGFR with afatinib and cetuximab in kinase inhibitor-resistant EGFR-mutant lung cancer with and without T790M mutations. Cancer Discov. 2014, 4, 1036-1045. [CrossRef]

14. NIH-Illuminating the Druggable Genome (IDG). Available online: https:/ / commonfund.nih.gov/IDG (accessed on 25 March 2021).

15. Oprea, T.I. Exploring the dark genome: Implications for precision medicine. Mamm. Genome 2019, 30, 192-200. [CrossRef] [PubMed] 
16. Wendler, F. The LMTK-family of kinases: Emerging important players in cell physiology and disease pathogenesis. Biochim. Biophys. Acta Mol. Basis Dis. 2018. [CrossRef] [PubMed]

17. Guy, M.; Kote-Jarai, Z.; Giles, G.G.; Al Olama, A.A.; Jugurnauth, S.K.; Mulholland, S.; Leongamornlert, D.A.; Edwards, S.M.; Morrison, J.; Field, H.I.; et al. Identification of new genetic risk factors for prostate cancer. Asian J. Androl. 2009, 11, 49-55. [CrossRef]

18. Kohaar, I.; Petrovics, G.; Srivastava, S. A rich array of prostate cancer molecular biomarkers: Opportunities and challenges. Int. J. Mol. Sci. 2019, 20, 1813. [CrossRef]

19. Bray, F.; Ferlay, J.; Soerjomataram, I.; Siegel, R.L.; Torre, L.A.; Jemal, A. Global cancer statistics 2018: GLOBOCAN estimates of incidence and mortality worldwide for 36 cancers in 185 countries. CA Cancer J. Clin. 2018, 68, 394-424. [CrossRef]

20. Wang, G.; Zhao, D.; Spring, D.J.; Depinho, R.A. Genetics and biology of prostate cancer. Genes Dev. 2018, 32, 1105-1140. [CrossRef]

21. Pernar, C.H.; Ebot, E.M.; Wilson, K.M.; Mucci, L.A. The Epidemiology of Prostate Cancer. Cold Spring Harb. Perspect. Med. 2018, 8 , a030361. [CrossRef]

22. Baade, P.D.; Youlden, D.R.; Krnjacki, L.J. International epidemiology of prostate cancer: Geographical distribution and secular trends. Mol. Nutr. Food Res. 2009, 53, 171-184. [CrossRef]

23. Kheirandish, P.; Chinegwundoh, F. Ethnic differences in prostate cancer. Br. J. Cancer 2011, 105, 481-485. [CrossRef]

24. Taitt, H.E. Global Trends and Prostate Cancer: A Review of Incidence, Detection, and Mortality as Influenced by Race, Ethnicity, and Geographic Location. Am. J. Mens. Health 2018, 12, 1807-1823. [CrossRef] [PubMed]

25. Tolkach, Y.; Kristiansen, G. The Heterogeneity of Prostate Cancer: A Practical Approach. Pathobiology 2018, 85, 108-116. [CrossRef]

26. Testa, U.; Castelli, G.; Pelosi, E. Cellular and Molecular Mechanisms Underlying Prostate Cancer Development: Therapeutic Implications. Medicines 2019, 6, 82. [CrossRef]

27. Karantanos, T.; Corn, P.G.; Thompson, T.C. Prostate cancer progression after androgen deprivation therapy: Mechanisms of castrate resistance and novel therapeutic approaches. Oncogene 2013, 32, 5501-5511. [CrossRef]

28. Reig, Ò.; Marín-Aguilera, M.; Carrera, G.; Jiménez, N.; Paré, L.; García-Recio, S.; Gaba, L.; Pereira, M.V.; Fernández, P.; Prat, A.; et al. TMPRSS2-ERG in Blood and Docetaxel Resistance in Metastatic Castration-resistant Prostate Cancer. Eur. Urol. 2016, 70, 709-713. [CrossRef]

29. Beltran, H.; Romanel, A.; Conteduca, V.; Casiraghi, N.; Sigouros, M.; Franceschini, G.M.; Orlando, F.; Fedrizzi, T.; Ku, S.Y.; Dann, E.; et al. Circulating tumor DNA profile recognizes transformation to castration-resistant neuroendocrine prostate cancer. J. Clin. Investig. 2020, 130, 1653-1668. [CrossRef]

30. Li, Y.K.; Moughan, J.; Al-Saleem, T.; Hammond, E.H.; Venkatesan, V.; Rosenthal, S.A.; Ritter, M.A.; Sandler, H.M.; Hanks, G.E.; Shipley, W.U.; et al. Bcl-2 and bax expression predict prostate cancer outcome in men treated with androgen deprivation and radiotherapy on radiation therapy oncology group protocol 92-02. Clin. Cancer Res. 2007, 13, 3585-3590. [CrossRef]

31. Yadav, S.; Anbalagan, M.; Baddoo, M.; Chellamuthu, V.K.; Mukhopadhyay, S.; Woods, C.; Jiang, W.; Moroz, K.; Flemington, E.K.; Makridakis, N. Somatic mutations in the DNA repairome in prostate cancers in African Americans and Caucasians. Oncogene 2020, 39, 4299-4311. [CrossRef] [PubMed]

32. Poulsen, M.H.; Feddersen, S.; Albitar, M.; Poulsen, C.A.; Lund, M.; Pedersen, T.B.; Mortensen, M.A.; Lund, L. A prospective study of a urine and plasma biomarker test for the prediction of gleason $\geq 3+4$ prostate cancer in a mixed cohort. Scand. J. Urol. 2020, 54, 323-327. [CrossRef]

33. Aslan, R.; Alp, H.H.; Eryılmaz, R.; Huyut, Z.; Sevim, M.; Araz, S.; Ertas, K.; Taken, K. Can the Irisin be a Biomarker for Prostate Cancer? A Case Control Study. Asian Pac. J. Cancer Prev. 2020, 21, 505-509. [CrossRef]

34. Liu, Z.; Zhong, J.; Cai, C.; Lu, J.; Wu, W.; Zeng, G. Immune-related biomarker risk score predicts prognosis in prostate cancer. Aging 2020, 12, 22776-22789. [CrossRef] [PubMed]

35. Wei, B.; Liang, J.; Hu, J.; Mi, Y.; Ruan, J.; Zhang, J.; Wang, Z.; Hu, Q.; Jiang, H.; Ding, Q. TRAF2 is a valuable prognostic biomarker in patients with prostate cancer. Med. Sci. Monit. 2017, 23, 4192-4204. [CrossRef]

36. Govers, T.M.; Caba, L.; Resnick, M.J. Cost-Effectiveness of Urinary Biomarker Panel in Prostate Cancer Risk Assessment. J. Urol. 2018, 200, 1221-1226. [CrossRef]

37. Huang, Y.; Pledgie, A.; Casero, R.A.; Davidson, N.E. Molecular mechanisms of polyamine analogs in cancer cells. Anticancer. Drugs 2005, 16, 229-241. [CrossRef]

38. Ramberg, H.; Grytli, H.H.; Nygård, S.; Wang, W.; Ögren, O.; Zhao, S.; Løvf, M.; Katz, B.; Skotheim, R.I.; Bjartell, A.; et al. PBX3 is a putative biomarker of aggressive prostate cancer. Int. J. Cancer 2016, 139, 1810-1820. [CrossRef]

39. Cai, B.; Peng, J.H. Increased expression of miR-494 in serum of patients with prostate cancer and its potential diagnostic value. Clin. Lab. 2019, 65, 1507-1512. [CrossRef]

40. Ikeda, S.; Elkin, S.K.; Tomson, B.N.; Carter, J.L.; Kurzrock, R. Next-generation sequencing of prostate cancer: Genomic and pathway alterations, potential actionability patterns, and relative rate of use of clinical-grade testing. Cancer Biol. Ther. 2019, 20, 219-226. [CrossRef]

41. Fraser, M.; Sabelnykova, V.Y.; Yamaguchi, T.N.; Heisler, L.E.; Livingstone, J.; Huang, V.; Shiah, Y.J.; Yousif, F.; Lin, X.; Masella, A.P.; et al. Genomic hallmarks of localized, non-indolent prostate cancer. Nature 2017, 541, 359-364. [CrossRef]

42. Taylor, B.S.; Schultz, N.; Hieronymus, H.; Gopalan, A.; Xiao, Y.; Carver, B.S.; Arora, V.K.; Kaushik, P.; Cerami, E.; Reva, B.; et al. Integrative Genomic Profiling of Human Prostate Cancer. Cancer Cell 2010, 18, 11-22. [CrossRef] [PubMed] 
43. Rodrigues, D.N.; Rescigno, P.; Liu, D.; Yuan, W.; Carreira, S.; Lambros, M.B.; Seed, G.; Mateo, J.; Riisnaes, R.; Mullane, S.; et al. Immunogenomic analyses associate immunological alterations with mismatch repair defects in prostate cancer. J. Clin. Investig. 2018, 128, 4441-4453. [CrossRef]

44. Bishop, M.R.; Huskey, A.L.W.; Hetzel, J.; Merner, N.D. A research-based gene panel to investigate breast, ovarian and prostate cancer genetic risk. PLoS ONE 2019, 14, e0220929. [CrossRef]

45. Cruz, D.F.; Farinha, C.M.; Swiatecka-Urban, A. Unraveling the function of lemur tyrosine kinase 2 network. Front. Pharm. 2019, 10, 24. [CrossRef]

46. Li, Z.; Wu, J.; Ji, M.; Shi, L.; Xu, B.; Jiang, J.; Wu, C. Prognostic role of lemur tyrosine kinase 3 in postoperative gastric cancer. Mol. Clin. Oncol. 2014, 2, 756-760. [CrossRef]

47. Jiang, T.; Lu, X.; Yang, F.; Wang, M.; Yang, H.; Xing, N. LMTK3 promotes tumorigenesis in bladder cancer via the ERK/MAPK pathway. FEBS Open Bio 2020, 10, 2107-2121. [CrossRef]

48. Conti, A.; Majorini, M.T.; Fontanella, E.; Bardelli, A.; Giacca, M.; Delia, D.; Mano, M.; Lecis, D. Lemur tyrosine kinase 2 (LMTK2) is a determinant of cell sensitivity to apoptosis by regulating the levels of the BCL2 family members. Cancer Lett. 2017, 389, 59-69. [CrossRef]

49. Zhang, R.; Li, X.; Wei, L.; Qin, Y.; Fang, J. Lemur tyrosine kinase 2 acts as a positive regulator of NF- $k B$ activation and colon cancer cell proliferation. Cancer Lett. 2019, 454, 70-77. [CrossRef]

50. Zhao, G.; Song, Y.; Dong, L.; Shi, H.; Li, H.; Yang, L.; Wang, J. Silencing of lemur tyrosine kinase 2 restricts the proliferation and invasion of hepatocellular carcinoma through modulation of GSK-3 $\beta / \mathrm{Wnt} / \beta$-catenin signaling. Biochem. Biophys. Res. Commun. 2019, 517, 722-728. [CrossRef] [PubMed]

51. Ditsiou, A.; Cilibrasi, C.; Simigdala, N.; Papakyriakou, A.; Milton-Harris, L.; Vella, V.; Nettleship, J.E.; Lo, J.H.; Soni, S.; Smbatyan, G.; et al. The structure-function relationship of oncogenic LMTK3. Sci. Adv. 2020, 6, eabc3099. [CrossRef]

52. Gaozza, E.; Baker, S.J.; Vora, R.K.; Reddy, E.P. AATYK: A novel tyrosine kinase induced during growth arrest and apoptosis of myeloid cells. Oncogene 1997, 15, 3127-3135. [CrossRef]

53. Wang, H.; Brautigan, D.L. A novel transmembrane Ser/Thr kinase complexes with protein phosphatase-1 and inhibitor-2. J. Biol. Chem. 2002, 277, 49605-49612. [CrossRef] [PubMed]

54. Bencze, J.; Mórotz, G.M.; Seo, W.; Bencs, V.; Kálmán, J.; Miller, C.C.J.; Hortobágyi, T. Biological function of Lemur tyrosine kinase 2 (LMTK2): Implications in neurodegeneration. Mol. Brain 2018, 11, 20. [CrossRef] [PubMed]

55. The UniProt Consortium. UniProt: A worldwide hub of protein knowledge. Nucleic Acids Res. 2019, 47, D506-D515. [CrossRef]

56. The Human Protein Atlas. Available online: https:/ / www.proteinatlas.org/ (accessed on 9 March 2021).

57. Shah, K.; Bradbury, N.A. Lemur tyrosine kinase 2, a novel target in prostate cancer therapy. Oncotarget 2015, 6, 14233-14246. [CrossRef] [PubMed]

58. Nixon, A.; Jia, Y.; White, C.; Bradbury, N.A. Determination of the membrane topology of lemur tyrosine kinase 2 (LMTK2) by fluorescence protease protection. Am. J. Physiol. Cell Physiol. 2013, 304, C164-C169. [CrossRef]

59. Omasits, U.; Ahrens, C.H.; Müller, S.; Wollscheid, B. Protter: Interactive protein feature visualization and integration with experimental proteomic data. Bioinformatics 2014, 30, 884-886. [CrossRef]

60. Harries, L.W.; Perry, J.R.B.; McCullagh, P.; Crundwell, M. Alterations in LMTK2, MSMB and HNF1B gene expression are associated with the development of prostate cancer. BMC Cancer 2010, 10, 315. [CrossRef]

61. Vezelis, A.; Simiene, J.; Dabkeviciene, D.; Kincius, M.; Ulys, A.; Suziedelis, K.; Jarmalaite, S.; Jankevicius, F. LMTK2 as Potential Biomarker for Stratification between Clinically Insignificant and Clinically Significant Prostate Cancer. J. Oncol. $2021,2021$. [CrossRef]

62. Vickman, R.E.; Franco, O.E.; Moline, D.C.; Vander Griend, D.J.; Thumbikat, P.; Hayward, S.W. The role of the androgen receptor in prostate development and benign prostatic hyperplasia: A review. Asian J. Urol. 2020, 7, 191-202. [CrossRef]

63. Fujita, K.; Nonomura, N. Role of androgen receptor in prostate cancer: A review. World J. Men Health 2019, 37, 288-295. [CrossRef]

64. Shah, K.; Bradbury, N.A. Kinase Modulation of Androgen Receptor Signaling: Implications for Prostate Cancer. Cancer Cell Microenviron. 2015, 2, e123. [CrossRef]

65. Dunn, T.A.; Chen, S.; Faith, D.A.; Hicks, J.L.; Platz, E.A.; Chen, Y.; Ewing, C.M.; Sauvageot, J.; Isaacs, W.B.; De Marzo, A.M.; et al. A novel role of myosin VI in human prostate cancer. Am. J. Pathol. 2006, 169, 1843-1854. [CrossRef] [PubMed]

66. Puri, C.; Chibalina, M.V.; Arden, S.D.; Kruppa, A.J.; Kendrick-Jones, J.; Buss, F. Overexpression of myosin VI in prostate cancer cells enhances PSA and VEGF secretion, but has no effect on endocytosis. Oncogene 2010, 29, 188-200. [CrossRef] [PubMed]

67. Manser, C.; Guillot, F.; Vagnoni, A.; Davies, J.; Lau, K.F.; McLoughlin, D.M.; De Vos, K.J.; Miller, C.C.J. Lemur tyrosine kinase-2 signalling regulates kinesin-1 light chain-2 phosphorylation and binding of Smad2 cargo. Oncogene 2012, 31, 2773-2782. [CrossRef] [PubMed]

68. Sun, P.; Sun, X.; Zhao, W.; Ren, M.; Zhang, C.; Wang, Z.; Xu, W. Lemur Tyrosine Kinase-3 Suppresses Growth of Prostate Cancer Via the AKT and MAPK Signaling Pathways. Cell. Physiol. Biochem. 2017, 42, 2582-2592. [CrossRef] [PubMed]

69. Shorning, B.Y.; Dass, M.S.; Smalley, M.J.; Pearson, H.B. The PI3K-AKT-mTOR pathway and prostate cancer: At the crossroads of AR, MAPK, and WNT signaling. Int. J. Mol. Sci. 2020, 21, 4507. [CrossRef] [PubMed]

70. Gao, S.; Bajrami, I.; Verrill, C.; Kigozi, A.; Ouaret, D.; Aleksic, T.; Asher, R.; Han, C.; Allen, P.; Bailey, D.; et al. Dsh homolog DVL3 mediates resistance to IGFIR inhibition by regulating IGF-RAS signaling. Cancer Res. 2014, 74, 5866-5877. [CrossRef]

71. Reynard, J.; Brewster, S.; Biers, S. Oxford Handbook of Urology, 3rd ed.; Oxford University Press: Oxford, UK, 2013. 
72. Livingstone, T.L.; Beasy, G.; Mills, R.D.; Plumb, J.; Needs, P.W.; Mithen, R.; Traka, M.H. Plant bioactives and the prevention of prostate cancer: Evidence from human studies. Nutrients 2019, 11, 2245. [CrossRef] [PubMed]

73. Thomas, R.; Williams, M.; Sharma, H.; Chaudry, A.; Bellamy, P. A double-blind, placebo-controlled randomised trial evaluating the effect of a polyphenol-rich whole food supplement on PSA progression in men with prostate cancer-The UK NCRN Pomi-T study. Prostate Cancer Prostatic Dis. 2014, 17, 180-186. [CrossRef]

74. Watson, G.; Beaver, L.; Williams, D.; Dashwood, R.; Ho, E. Phytochemicals from cruciferous vegetables, epigenetics, and prostate cancer prevention. AAPS J. 2013, 15, 951-961. [CrossRef]

75. Negri, A.; Naponelli, V.; Rizzi, F.; Bettuzzi, S. Molecular targets of epigallocatechin—gallate (EGCG): A special focus on signal transduction and cancer. Nutrients 2018, 10, 1936. [CrossRef] [PubMed]

76. Bettuzzi, S.; Brausi, M.; Rizzi, F.; Castagnetti, G.; Peracchia, G.; Corti, A. Chemoprevention of human prostate cancer by oral administration of green tea catechins in volunteers with high-grade prostate intraepithelial neoplasia: A preliminary report from a one-year proof-of-principle study. Cancer Res. 2006, 66, 1234-1240. [CrossRef] [PubMed]

77. Miyata, Y.; Shida, Y.; Hakariya, T.; Sakai, H. Anti-cancer effects of green tea polyphenols against prostate cancer. Molecules 2019, 24, 193. [CrossRef] [PubMed]

78. Ghanavati, M.; Clark, C.C.T.; Bahrami, A.; Teymoori, F.; Movahed, M.; Sohrab, G.; Hejazi, E. Dietary intake of polyphenols and total antioxidant capacity and risk of prostate cancer: A case-control study in Iranian men. Eur. J. Cancer Care 2021, 30 , e13364. [CrossRef]

79. Singh, S.K.; Banerjee, S.; Acosta, E.P.; Lillard, J.W.; Singh, R. Resveratrol induces cell cycle arrest and apoptosis with docetaxel in prostate cancer cells via a p53/p21WAF1/CIP1 and p27KIP1 pathway. Oncotarget 2017, 8, 17216-17228. [CrossRef]

80. Costea, T.; Vlad, O.C.; Miclea, L.C.; Ganea, C.; Szöllősi, J.; Mocanu, M.M. Alleviation of multidrug resistance by flavonoid and non-flavonoid compounds in breast, lung, colorectal and prostate cancer. Int. J. Mol. Sci. 2020, 21, 401. [CrossRef]

81. Perletti, G.; Magri, V.; Vral, A.; Stamatiou, K.; Trinchieri, A. Green tea catechins for chemoprevention of prostate cancer in patients with histologically-proven HG-PIN or ASAP. Concise review and meta-analysis. Arch. Ital. Urol. Androl. 2019, 91, 153-156. [CrossRef] [PubMed]

82. Costea, T.; Nagy, P.; Ganea, C.; Szöllősi, J.; Mocanu, M.M. Molecular mechanisms and bioavailability of polyphenols in prostate cancer. Int. J. Mol. Sci. 2019, 20, 1062. [CrossRef]

83. Tauber, A.L.; Schweiker, S.S.; Levonis, S.M. From tea to treatment; epigallocatechin gallate and its potential involvement in minimizing the metabolic changes in cancer. Nutr. Res. 2020, 74, 23-36. [CrossRef]

84. Shankar, S.; Suthakar, G.; Srivastava, R.K. Epigallocatechin-3-gallate inhibits cell cycle and induces apoptosis in pancreatic cancer. Front. Biosci. 2007, 12, 5039-5051. [CrossRef]

85. Lee, Y.H.; Kwak, J.; Choi, H.K.; Choi, K.C.; Kim, S.; Lee, J.; Jun, W.; Park, H.J.; Yoon, H.G. EGCG suppresses prostate cancer cell growth modulating acetylation of androgen receptor by anti-histone acetyltransferase activity. Int. J. Mol. Med. 2012, 30, 69-74. [CrossRef]

86. Li, M.; He, Z.; Ermakova, S.; Zheng, D.; Tang, F.; Cho, Y.Y.; Zhu, F.; Ma, W.Y.; Sham, Y.; Rogozin, E.A.; et al. Direct inhibition of insulin-like growth factor-I receptor kinase activity by (-)-epigallocatechin-3-gallate regulates cell transformation. Cancer Epidemiol. Biomark. Prev. 2007, 16, 598-605. [CrossRef]

87. Shao, N.; Tang, H.; Mi, Y.; Zhu, Y.; Wan, F.; Ye, D. A novel gene signature to predict immune infiltration and outcome in patients with prostate cancer. Oncoimmunology 2020, 9, 1762473. [CrossRef] [PubMed]

88. Komisarof, J.; McCall, M.; Newman, L.; Bshara, W.; Mohler, J.L.; Morrison, C.; Land, H. A four gene signature predictive of recurrent prostate cancer. Oncotarget 2017, 8, 3430-3440. [CrossRef]

89. Rizzi, F.; Belloni, L.; Crafa, P.; Lazzaretti, M.; Remondini, D.; Ferretti, S.; Cortellini, P.; Corti, A.; Bettuzzi, S. A novel gene signature for molecular diagnosis of human prostate cancer by RT-qPCR. PLoS ONE 2008, 3, e3617. [CrossRef]

90. Ruscetti, M.A.; Wu, H. PTEN in Prostate Cancer. In Prostate Cancer Protein Reviews; Springer: New York, NY, USA, 2013; pp. 87-137.

91. Toren, P.; Zoubeidi, A. Targeting the PI3K/Akt pathway in prostate cancer: Challenges and opportunities (Review). Int. J. Oncol. 2014, 45, 1793-1801. [CrossRef] [PubMed]

92. Braglia, L.; Zavatti, M.; Vinceti, M.; Martelli, A.M.; Marmiroli, S. Deregulated PTEN/PI3K/AKT/mTOR signaling in prostate cancer: Still a potential druggable target? Biochim. Biophys. Acta Mol. Cell Res. 2020, 1867, 9. [CrossRef]

93. Chibalina, M.V.; Seaman, M.N.J.; Miller, C.C.; Kendrick-Jones, J.; Buss, F. Myosin VI and its interacting protein LMTK2 regulate tubule formation and transport to the endocytic recycling compartment. J. Cell Sci. 2007, 120, 4278-4288. [CrossRef] [PubMed]

94. Dey, I.; Bradbury, N.A. Activation of TPA-response element present in human Lemur Tyrosine Kinase 2 (lmtk2) gene increases its expression. Biochem. Biophys. Rep. 2017, 12, 140-150. [CrossRef] 